\title{
Evaluation of the Antidepressant-like Activity of the Crude Extract and Solvent Fractions of Rosa Abyssinica Lindley (Rosaceae) Using Rodent Models of Depression
}

\section{Fekadu $\mathbf{N}^{1}$, Shibeshi $\mathbf{W}^{2}$ and Engidawork $\mathrm{E}^{2^{*}}$}

${ }^{1}$ Directorate of Traditional and Modern Medicine Research, Ethiopian Public Health Institute, Addis Ababa 1242, Ethiopia

${ }^{2}$ Department of Pharmacology and Clinical Pharmacy, School of Pharmacy, Addis Ababa University, Addis Ababa 1176, Ethiopia

"Corresponding author: Engidawork E, Department of Pharmacology and Clinical Pharmacy, School of Pharmacy, Addis Ababa University, Addis Ababa 1176, Ethiopia, E-mail: ephrem.engidawork@gmail.com

Received date: April 08, 2016; Accepted date: May 05, 2016; Published date: May 09, 2016

Copyright: () 2016 Fekadu N, et al. This is an open-access article distributed under the terms of the Creative Commons Attribution License, which permits unrestricted use, distribution, and reproduction in any medium, provided the original author and source are credited.

\begin{abstract}
Background: The fruit of Rosa abyssinica Lindley (Rosaceae) is claimed to alleviate depression in folkloric Ethiopian medicine. Nevertheless, the antidepressant-like effect has not been assessed in rodent models of depression.

Methods: The test animals were randomly selected and divided into five groups $(\mathrm{n}=8)$. Group I and II received $2 \%$ Tween 80 and the standard drug imipramine $(30 \mathrm{mg} / \mathrm{kg}$ ) respectively while Groups III to V received increasing doses of the extracts and duration of immobility at three dose levels of the crude extract and (100, 200, and 400 $\mathrm{mg} / \mathrm{kg}$ ) was the parameter determined to assess the antidepressant-like activity of $R$. abyssinica in tail suspension test (TST) and forced swimming test (FST). The locomotor activity was also evaluated in terms of number of square crossings using the open field test (OFT) in order to rule out possible psycho-stimulant activity.
\end{abstract}

Results: The crude extract at the doses of $200 \mathrm{mg} / \mathrm{kg}$ and $400 \mathrm{mg} / \mathrm{kg}$ significantly reduced the time of immobility in the TST and FST. The aqueous fraction at $200 \mathrm{mg} / \mathrm{kg}$ displayed a significant reduction of $38 \%$ in the duration of immobility in TST which was superior to the effect of imipramine. The methanol fraction displayed a significant reduction in the duration of immobility of $33.93 \%$ only at $200 \mathrm{mg} / \mathrm{kg}$. The ethyl acetate fraction was devoid of activity. No significant change in locomotor activity was detected in all the doses of the crude extract and imipramine in OFT.

Conclusion: The results of this study suggest that this plant possesses an appreciable antidepressant-like activity.

Keywords: Anti-depressants; Despair based models of depression; Rosa abyssinica; Acute toxicity

\section{Abbreviations:}

R. abyssinica: Rosa abyssinica; TST: Tail Suspension Test; FST: Forced Swimming Test; OFT: Open Field Test; OECD: Organization for Economic Cooperation and Development Guideline

\section{Introduction}

Depression is a chronic mental disorder that causes changes in mood, thoughts, behavior and physical health [1]. According to the World Health Organization (WHO) unipolar depression is one of the leading causes of disability- adjusted life year (DALY) and approximately 350 million people worldwide are said to suffer from this mental disorder [2]. Over the years, plenty of drugs have been developed for the management of depression; however, one of the challenges in dealing with this disease is that a significant portion of the patients taking antidepressants fail to attain full remission [3]. For decades, depression pharmacotherapy focused on the brain monoamine neurotransmitters level following the serendipitous discovery of imipramine and iproniazid as antidepressants $[4,5]$.
Diverse theories have been proposed to elucidate the pathophysiology of depressive disorders, some that have gained recognition are: abnormalities in the areas of the brain that are responsible for the regulation of mood, reward response and executive functions [5,6]. Structural brain abnormalities have been documented in patients with chronic stress and hyperactivity of the hypothalamic pituitary adrenal (HPA) axis $[7,8]$. Genetic polymorphisms on genes encoding the serotonin transporter (5-HTT), tryptophan hydroxylase (TPH), brain derived neurotrophic factors BDNF also has been linked with the pathogenesis of depression. Perhaps the most popular theory is the biogenic monoamine theory of depression which relates depression to a dysfunction in the brain serotonergic noradrenergic as well as dopaminergic system [9-13].

Herbal medicine has long been a reasonable alternative for the management of mental disorders such as anxiety, depression and dementia among plenty others [14]. Hypericum perforatum commonly known as St. John's wort is the only herbal antidepressant that has been approved for the clinical management of mild to moderate cases of depression [15]. Developing antidepressants from herbal sources seems to be reasonable approach due to their therapeutic efficacy and lower incidence of side effects [16]. 
Rosa abyssinica Lindley locally known as "kega" is an evergreen shrub that holds a high value in the Ethiopian folk medicine. It is used for the treatment of rheumatic pain, hypertension, scabies, cough, glandular tuberculosis and diabetes. The edible fruits which are adored by children are good tapeworm and round worm expectorants as well as excellent source of vitamins [17]. The root extract of the plant also possesses a genuine anti-nociceptive and anti-inflammatory activity [18]. Thirty-five components were identified in the essential oil extracted from the aerial parts of Rosa abyssinica including the flowers. The main components were $\gamma$-muurolene $(13.0 \%)$ and caryophyllene oxide (26.6\%) [19]. An ethno biological survey conducted in Tara Gedam and Amba remnant forests (South Gondar zone, Ethiopia) which focused on plants used in traditional medicine and as wild foods around the area reported that the whole fruits of Rosa abyssinica are consumed for the management of depression and stress related symptoms by the locals [20]. This study therefore attempts to scientifically justify the use of this plant as no prior studies have been carried out in this regard. Other species within the genus Rosa that are claimed to have antidepressant activity are Rosa canina and Rosa damascena which also have beneficial effects on stress and tension [21].

\section{Materials and Methods}

\section{Chemicals}

Imipramine (Torrent Pharmaceuticals, India), absolute methanol (Cheshire, UK), Tween 80 (BDH chemical reagents, England), petroleum ether (Carlo Erba reagents, France), ethyl acetate (Fluka, Germany), chloroform (BDH chemical reagents, England), ethyl alcohol (Changshu Yangyuan chemicals, China), distilled water, dilute ammonia, acetic anhydride, Dragendrof's reagent, $10 \%$ ethanolic ferric chloride, concentrated sulfuric acid, glacial acetic acid, 5\% ethanolic ferric chloride, $1 \% \mathrm{KFe}(\mathrm{CN}) 6,10 \%$ sodium nitrate, $2 \%$ lead acetate, $1 \%$ ferric chloride and $1 \%$ aqueous hydrochloric acid were purchased from reliable sources and were of analytical grade.

\section{Plant material collection and authentication}

The fruits of Rosa abyssinica were collected from Debre Tsigie; a town in northern Shewa, located $89 \mathrm{~km}$ from the capital. The plant material was identified by Ato Melaku Wondafrash, a taxonomist, and a voucher specimen (\# 001) was deposited at the National Herbarium for future reference.

\section{Extraction procedures}

Crude extract: The crude extract was obtained by three cycles of maceration of the fresh fruits with $80 \%$ methanol for $24 \mathrm{~h}$ at room temperature. The extract solution was then filtered, first by using cotton gauze and later by suction filtration apparatus (Oakton, USA) using Whatman filter paper (No. 1). Rotavapor (Büchi, Switzerland) was used to dry the methanol in the sample under reduced pressure at a temperature of $40^{\circ} \mathrm{C}$ and the remaining water was freeze dried by the use of a lyophilizer (Delvac, India). The extract obtained had a distinctive translucent amber color and a thick and sticky honey-like consistency. The percentage yield for the crude extract was calculated to be $15.8 \% \mathrm{w} / \mathrm{w}$.

Solvent fractions: The crude extract of the fruits of Rosa abyssinica $(30 \mathrm{~g})$ was defatted with petroleum ether using a soxhlet apparatus. Then the remaining marc was allowed to dry overnight and fractionated with the same apparatus using different solvents of increasing polarity namely ethyl acetate and methanol (100\%) to obtain the corresponding fractions. The marc left was then macerated with distilled water to obtain the aqueous fraction. Each fraction then was dried in an oven at $40^{\circ} \mathrm{C}$ and was stored in a refrigerator until further use.

\section{Experimental animals}

Animals used for this study were male albino Swiss mice (6-8 weeks, 20-30 g) as well as Sprague-Dawley rats (8-12 weeks, 200-250 g). The animals were housed in groups of 8 and were allowed to acclimatize to laboratory conditions for a minimum of 5 days before the time of experimentation. All animals had free access to standard animal feed and clean water and were maintained on a 12/12 hours of light/dark cycle. The ambient temperature was $22 \pm 3^{\circ} \mathrm{C}$. All animals used in the study were cared for and treated humanely throughout the study period following international guidelines [22]. Ethical clearance for this study was obtained from the School of Pharmacy, Addis Ababa University.

\section{Acute toxicity test}

Acute toxicity study was carried out using the limit test dose of 2000 $\mathrm{mg} / \mathrm{kg}$ as has been described by Organization for Economic Cooperation and Development (OECD) guideline [22]. A total of five female rats were fasted for $4 \mathrm{~h}$ and were administered with the limit dose $2000 \mathrm{mg} / \mathrm{kg}$ of the crude extract of $R$. abyssinica. The animals were then observed individually for mortality and overt signs of toxicity during the first $30 \mathrm{~min}$, periodically during the first $24 \mathrm{~h}$, with special attention given during the first $4 \mathrm{~h}$ and daily afterward for a total of 14 days. Mortality and any change in behaviors such as alertness, motor activity, breathing, restlessness, diarrhea, convulsions and coma were observed carefully.

\section{Experimental design}

All animals were randomly assigned to five different groups for each model. Group I received the vehicle ( $2 \%$ Tween 80 in distilled water) and served as negative control. Group II received the standard drug imipramine $(30 \mathrm{mg} / \mathrm{kg})$ and served as positive $[23,24]$. The test groups were group III-V, which received increasing doses of the extract or the solvent fractions at $100 \mathrm{mg} / \mathrm{kg}, 200 \mathrm{mg} / \mathrm{kg}$ and $400 \mathrm{mg} / \mathrm{kg}$, respectively. The different doses of the extract, the solvent fractions and the standard drug were dissolved in $2 \%$ Tween 80 solution immediately prior to use and administered orally one hour before the experiment sessions and maximum volume administered was $10 \mathrm{ml} / \mathrm{kg}$.

\section{Tail suspension test}

The tail suspension test (TST) is based on the fact that animals subjected to the short-term, inescapable stress of being suspended by their tail, will develop an immobile posture [25-27]. This protocol is conceptually related to the forced swim test (FST) [28]. After $60 \mathrm{~min}$ of administration of the treatment as per the respective grouping, male mice were hung upside down from a counter top of $50 \mathrm{~cm}$ of height using an adhesive tape placed approximately $1 \mathrm{~cm}$ from the tip of their tails. The mice were judged to be immobile when they hanged motionless, making only those movements necessary for respiration. The duration of immobility was recorded for 6 min using a stopwatch and the results were obtained as time scale (in seconds) and percentage inhibition of immobility [29]. 
Page 3 of 7

\section{Forced swim test}

Male rats were forced to swim individually in a transparent glass container $(20 \mathrm{~cm}$ in diameter and height of $40 \mathrm{~cm})$ containing fresh water of $19 \mathrm{~cm}$ height which was maintained at $25^{\circ} \mathrm{C}\left( \pm 3^{\circ} \mathrm{C}\right)$. There were two sessions; in the first session (pre-test) the untreated male rats were allowed to swim in the container for 15 min each without any behavioral recording. This was done in order to check the fitness level of each animal and to obtain a stable immobility time profile [30]. In the second session ( $24 \mathrm{~h}$ after the pre-test), the rats were allowed to swim for $5 \mathrm{~min}$ following treatment $(60 \mathrm{~min}, 4 \mathrm{~h}$ and $24 \mathrm{~h}$ before the test) and the total duration of immobility was recorded using a stopwatch $[31,32]$. The rats were judged to be immobile when they remained floating without struggling, and making movements necessary only to keep their heads above the water. On the contrary, swimming was defined active escape or struggling movements such as head dipping, paddling with all four legs, circling the tank, and clambering at the walls [25]. Fresh water was replaced after each rat. Following the sessions, each rat was dried with a towel and placed in a rodent heater (UGO basile, Italy) before it was returned to its cage [33]. Results were obtained as time scale (in seconds) and percentage inhibition of immobility.

\section{Open field test}

Open field test (OFT) was carried out in order to rule out any nonspecific locomotor effect the extract might possess. Mice were administered with the same doses that produced anti-immobility effects in the TST and FST to assess their effect on locomotor activity using the open-field paradigm. Briefly, after an hour of dosing, the animals were individually placed in the center of the OFT apparatus, which is a simple cubic dark wooden box $(68 \mathrm{~cm} \times 68 \mathrm{~cm} \times 45 \mathrm{~cm})$ with the floor divided into 16 squares to make up the central and peripheral squares [34]. The OFT apparatus was illuminated by a $60 \mathrm{~W}$ bulb placed perpendicularly above it. Number of peripheral crossings (ambulation), activity in the center (central crossings) and total locomotion, which are the sum of the two, were recorded for $5 \mathrm{~min}$. The surface of the apparatus was cleaned with alcohol and cotton swab after each mouse to avoid potential cues. Caution was taken not to make any sudden movement and sound noise was reduced as much as possible [34]. The results were obtained as number of crossings (Peripheral, Central, and total crossings) on the open field arena.

\section{Preliminary phytochemical screening and TLC analysis}

Phytochemical screening: The $80 \%$ methanol crude extract of $R$. abyssinica and its solvent fractions were used to run various preliminary phytochemical screening tests. This was done to verify the presence or absence of certain secondary metabolites following standard procedures as described in Trease and Evans [35].

Data analysis: The data obtained from the experiment was evaluated by SPSS windows version 16.0 using one-way analysis of variance (ANOVA) followed by Tukey's post-Hoc analysis. All the results observed from the experiment were expressed as mean \pm S.E.M and level of significance was set at $\mathrm{p}<0.05$.

\section{Results}

\section{Acute toxicity study}

The acute toxicity study revealed the non-toxic nature of the $80 \%$ methanolic fruit extracts of $R$. abyssinica at a limit dose of $2000 \mathrm{mg} / \mathrm{kg}$. This finding suggests the LD50 of the extract to be above $2000 \mathrm{mg} / \mathrm{kg}$ as no signs of overt toxicity and mortality were observed in the extracttreated animals. Moreover, the extract did not produce significant changes in behaviors such as alertness, restlessness, breathing, diarrhea, convulsions and coma during the observation period of two weeks.

\section{Effect of the crude extract in mice tail suspension test}

At the dose of $100 \mathrm{mg} / \mathrm{kg}$, the crude extract showed $12.8 \%$ reduction in the duration of immobility which was insignificant (Table 1). On the other hand, at the dose of $200 \mathrm{mg} / \mathrm{kg}(24.7 \%, \mathrm{p}<0.01)$ the extract exhibited a significant reduction in immobility. The extract exhibited its highest effect at the dose of $400 \mathrm{mg} / \mathrm{kg}$. The standard drug imipramine exhibited the highest percentage reduction in immobility compared to the other groups (43.0\%). Moreover, no statistically significant difference was observed between the effect produced by imipramine and $400 \mathrm{mg} / \mathrm{kg}$ of the extract.

\begin{tabular}{|l|l|l|}
\hline Treatment groups & $\begin{array}{l}\text { Duration } \\
\text { immobility(s) }\end{array}$ & $\begin{array}{l}\text { Percent reduction } \\
\text { in time of } \\
\text { immobility }\end{array}$ \\
\hline Control & $160.4 \pm 7.1$ & - \\
\hline Imipramine $30 \mathrm{mg} / \mathrm{kg}$ & $91.4 \pm 4.7 \mathrm{a}^{* *}, \mathrm{c}^{* *}$ & 43 \\
\hline RA $100 \mathrm{mg} / \mathrm{kg}$ & $139.9 \pm 7.1 \mathrm{~b}^{* *}$ & 12.8 \\
\hline RA $200 \mathrm{mg} / \mathrm{kg}$ & $120.6 \pm 7.5 \mathrm{a}^{* *}, \mathrm{~b}^{*}$ & 24.7 \\
\hline RA $400 \mathrm{mg} / \mathrm{kg}$ & $100.9 \pm 5.1 \mathrm{a}^{* *}, \mathrm{c}^{* *}$ & 37.1 \\
\hline
\end{tabular}

Values represent mean \pm SEM $(n=8)$; a compared to control; b compared to standard; c compared to to $100 \mathrm{mg} / \mathrm{kg}$; ${ }^{*} p<0.05$, ${ }^{* *} p<0.01$; Control received $2 \%$ Tween 80 in distilled water; RA = Rosa abyssinica crude extract

Table 1: Effect of $80 \%$ methanol fruit extract of Rosa abyssinica on duration of immobility in mice tail suspension test.

\section{Effect of the crude extract in rat forced swim test}

As seen in the TST, the extract at the dose of $100 \mathrm{mg} / \mathrm{kg}$ failed to show a marked decrease in immobility $(9.71 \%)$ compared with the control group (Table 2). The test dose of $200 \mathrm{mg} / \mathrm{kg}$, on the other hand, was able to exhibit a significantly higher percentage reduction in immobility time $(33.6 \%, \mathrm{p}<0.01)$.

A similar but greater reduction in duration of immobility was also observed at $400 \mathrm{mg} / \mathrm{kg}(35.6 \%, \mathrm{p}<0.01)$. Imipramine displayed the highest percentage reduction (36.7\%) in the duration of immobility in comparison with both the vehicle and extract treated groups.

\section{Effect of the crude extract on locomotion in the open field test}

The outcome of the test revealed that the doses of the extract that were able to display antidepressant-like response, did not exhibit significant change in locomotion (Table 3). The total square crossing 
Page 4 of 7

recorded after administering doses $200 \mathrm{mg} / \mathrm{kg}(4.7 \%)$ and $400 \mathrm{mg} / \mathrm{kg}$ (16.1\%) though not significant, were higher than all the other groups. The plant at $100 \mathrm{mg} / \mathrm{kg}$ displayed an insignificant decrease of $8.4 \%$ in total locomotion. The groups receiving imipramine and the vehicle had comparable total locomotion. On the other hand, central crossings for the extract treated animals seemed to be highest for the lowest dose $(100 \mathrm{mg} / \mathrm{kg})$, though the difference was not statistically significant compared to the control.

\begin{tabular}{|c|c|c|}
\hline Treatment group & $\begin{array}{l}\text { Duration of } \\
\text { immobility(s) }\end{array}$ & $\begin{array}{l}\text { Percent reduction in } \\
\text { time of immobility }\end{array}$ \\
\hline Control & $151.9 \pm 11.18$ & - \\
\hline Impiramine $30 \mathrm{mg} / \mathrm{kg}$ & $96.1 \pm 9.45 a^{* *}, c^{* *}$ & 36.7 \\
\hline $\mathrm{RA} 100 \mathrm{mg} / \mathrm{kg}$ & $137.1 \pm 4.3 b^{*}$ & 9.7 \\
\hline $\mathrm{RA} 200 \mathrm{mg} / \mathrm{kg}$ & $100.9 \pm 5.9 a^{* *}, c^{*}$ & 33.6 \\
\hline $\mathrm{RA} 400 \mathrm{mg} / \mathrm{kg}$ & $97.9 \pm 5.8 a^{* *}, c^{* *}$ & 35.6 \\
\hline
\end{tabular}

Values represent mean \pm SEM $(n=8)$; a compared to control; b compared to standard; c compared to $100 \mathrm{mg} / \mathrm{kg}$; ${ }^{*} p<0.05,{ }^{* *} \mathrm{P}<0.01$; Control received $2 \%$ Tween 80 in distilled water; RA = Rosa abyssinica crude extract

Table 2: Effect of $80 \%$ methanol extract of fruit of Rosa abyssinica in rat forced swim test.

\begin{tabular}{|l|l|l|l|l|}
\hline $\begin{array}{l}\text { Treatment } \\
\text { group }\end{array}$ & \multicolumn{2}{|l|}{ Number of crossings } & $\begin{array}{l}\text { Percent } \\
\text { change in } \\
\text { total } \\
\text { locomotion }\end{array}$ \\
\hline & $\begin{array}{l}\text { Peripheral } \\
\text { squares }\end{array}$ & $\begin{array}{l}\text { Central } \\
\text { squares }\end{array}$ & $\begin{array}{l}\text { Total } \\
\text { squares }\end{array}$ & \\
\hline Control & $60.2 \pm 10.8$ & $7.2 \pm 2.3$ & $67.3 \pm 12.7$ & - \\
\hline $\begin{array}{l}\text { Imipramine } 30 \\
\text { mg/kg }\end{array}$ & $60.7 \pm 10.0$ & $5.5 \pm 1.3$ & $66.2 \pm 11.0$ & -1.7 \\
\hline RA 200 mg/kg & $67.5 \pm 10.8$ & $3.0 \pm 0.7$ & $70.5 \pm 11.2$ & 4.7 \\
\hline RA 400 mg/kg & $74.5 \pm 8.3$ & $3.7 \pm 0.8$ & $78.2 \pm 8.8$ & 16.1 \\
\hline
\end{tabular}

Values represent mean \pm SEM $(n=8)$; $(-$ sign indicates decrease in total locomotion); Controls received $2 \%$ Tween 80 dissolved in distilled water; $\mathrm{RA}=$ Rosa abyssinica crude extract

Table 3: Effect of $80 \%$ methanol extract of Rosa abyssinica on locomotion and exploratory behaviors in mice open field test.

\section{Effect of the solvent fractions in mice tail suspension test}

The antidepressant-like activity of the aqueous, methanol and ethyl acetate fractions of the crude extract of $R$. abyssinica was evaluated using the mice tail suspension test (Table 4). The different test doses of the aqueous fraction exhibited a considerable antidepressant-like effect. At $100 \mathrm{mg} / \mathrm{kg}$, duration of immobility was decreased by $19.8 \%$ (Figure 1) compared to the control group, which failed to reach statistical significance. Both $200 \mathrm{mg} / \mathrm{kg}$ and $400 \mathrm{mg} / \mathrm{kg}$ doses significantly reduced duration of immobility by $38 \%(\mathrm{p}<0.01)$ and $30 \%$ $(\mathrm{p}<0.05)$, respectively. This effect was comparable to that produced by the standard drug and the effect of $200 \mathrm{mg} / \mathrm{kg}$ seemed to be even better than imipramine (36.7\%).
The methanol fraction at the lowest test dose $(100 \mathrm{mg} / \mathrm{kg})$, slightly decreased immobility time $(24.9 \%)$, which was found to be insignificant. However, at $200 \mathrm{mg} / \mathrm{kg}$, there was a marked decrease in the duration of immobility with a percentage reduction of $31 \%$ $(p<0.05)$ relative to control. This effect was also comparable to the effect to that observed with the standard drug imipramine which exhibited a $33.9 \%$ reduction $(\mathrm{p}<0.01)$ compared to the control group. Surprisingly, the highest dose of $400 \mathrm{mg} / \mathrm{kg}$, the methanol fraction displayed the least effect $(10.1 \%)$ in reduction of immobility, which was not significantly different to that noted with control groups (Figure 1).

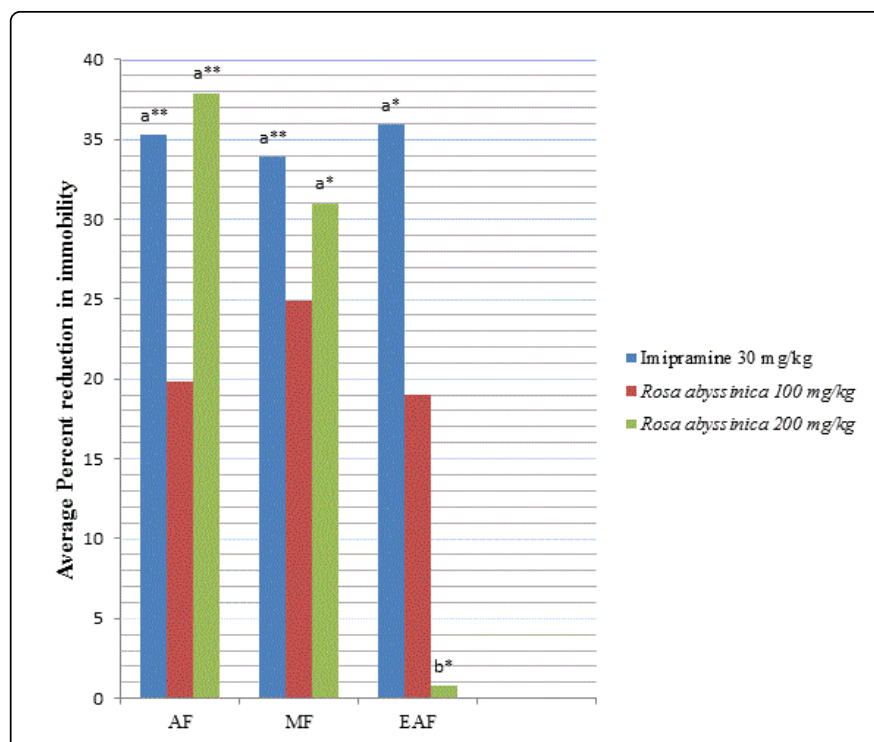

Figure 1: Effect of the solvent fractions of the crude extract of the fruits of Rosa abyssinica on the average percentage reduction of immobility time in mice tail suspension test $(\mathrm{n}=8)(\mathrm{AF}=$ Aqueous fraction; $\mathrm{MF}=$ Methanol fraction; $\mathrm{EAF}=$ Ethylacetate fraction) Values represent average percent reduction in immobility; a compared to control; b compared to standard; ${ }^{*} \mathrm{p}<0.05,{ }^{* *} \mathrm{p}<0.01$ ).

All doses of the ethyl acetate fraction failed to exhibit a significant reduction in the duration of immobility compared to controls, although they tended to produce a varying degree of reduction, with the highest effect noted with $100 \mathrm{mg} / \mathrm{kg}$. The effect produced with the standard drug (35.9\%) was significantly greater than that of $200 \mathrm{mg} / \mathrm{kg}$ $(\mathrm{p}<0.05)$ and $400 \mathrm{mg} / \mathrm{kg}(\mathrm{p}<0.05)$.

\section{Preliminary phytochemical screening}

Both the crude extract and fractions appeared to have by and large a similar profile of secondary metabolites (Table 5). Constituents such as alkaloids, saponins and terpenoids were absent. In contrast, polyphenols and tannins were detected in both the crude extract and its fractions. The polyphenolic compounds detected in the fruits of $R$. abyssinica include flavonoids and tannins. Flavonoids are valued for their appreciable anti-inflammatory and CNS action [36]. Tannins isolated from certain plants have been shown to possess antidepressant activities [37].

\section{TLC fingerprint}

TLC analysis was performed using various combinations of solvent systems. The solvent system containing a mixture of hexane and ethyl 
Citation: Fekadu N, Shibeshi W, Engidawork E (2016) Evaluation of the Antidepressant-like Activity of the Crude Extract and Solvent Fractions of Rosa Abyssinica Lindley (Rosaceae) Using Rodent Models of Depression. Clin Exp Pharmacol 6: 207. doi:10.4172/2161-1459.1000207

Page 5 of 7

acetate produced a better separation of the constituents. The analysis revealed the presence of at least six compounds indicated by the red $\operatorname{dot}$ (Figure 2).

\begin{tabular}{|c|c|c|}
\hline Solvent fractions & Animal Group & Duration of immobility \\
\hline \multirow[t]{5}{*}{ Aqueous fraction } & $\mathrm{CON}$ & $151.0 \pm 10.6$ \\
\hline & IMP $30 \mathrm{mg} / \mathrm{kg}$ & $97.8 \pm 7.6 a^{\star *}$ \\
\hline & AF $100 \mathrm{mg} / \mathrm{kg}$ & $121.1 \pm 8.4$ \\
\hline & AF $200 \mathrm{mg} / \mathrm{kg}$ & $93.8 \pm 10.9^{\mathrm{a}^{* \star}}$ \\
\hline & AF $400 \mathrm{mg} / \mathrm{kg}$ & $113.8 \pm 5.6^{\mathrm{a}^{*}}$ \\
\hline \multirow[t]{5}{*}{ Methanol fraction } & CON & $144.4 \pm 9.6$ \\
\hline & IMP $30 \mathrm{mg} / \mathrm{kg}$ & $95.4 \pm 6.9^{\mathrm{a}^{* *}}$ \\
\hline & $\mathrm{MF} 100 \mathrm{mg} / \mathrm{kg}$ & $108.4 \pm 16.2$ \\
\hline & MF $200 \mathrm{mg} / \mathrm{kg}$ & $99.6 \pm 7.3^{\mathrm{a}^{*}}$ \\
\hline & $\mathrm{MF} 400 \mathrm{mg} / \mathrm{kg}$ & $129.9 \pm 3.4$ \\
\hline \multirow[t]{5}{*}{ Ethyl acetate fraction } & $\mathrm{CON}$ & $141.3 \pm 7.1$ \\
\hline & IMP $30 \mathrm{mg} / \mathrm{kg}$ & $90.5 \pm 5.9^{\mathrm{a}^{*}}$ \\
\hline & $\mathrm{EAF} 100 \mathrm{mg} / \mathrm{kg}$ & $114.4 \pm 14.1$ \\
\hline & $\mathrm{EAF} 200 \mathrm{mg} / \mathrm{kg}$ & $140.1 \pm 15.9^{b^{*}}$ \\
\hline & $\mathrm{EAF} 400 \mathrm{mg} / \mathrm{kg}$ & $144.0 \pm 6.9^{b^{*}}$ \\
\hline
\end{tabular}

Table 4: Effect of the solvent fractions of the fruits of Rosa abyssinica on duration of immobility in mice tail suspension test.

\begin{tabular}{|c|c|c|c|c|}
\hline \multirow{2}{*}{$\begin{array}{l}\text { Secondary } \\
\text { metabolites tested }\end{array}$} & \multirow{2}{*}{$\begin{array}{l}\text { Crude } \\
\text { extract } \\
\text { of Rosa } \\
\text { abyssinica }\end{array}$} & \multicolumn{3}{|c|}{ Solvent fractions } \\
\hline & & $\begin{array}{l}\text { Aqueous } \\
\text { fraction }\end{array}$ & $\begin{array}{l}\text { Methanol } \\
\text { fraction }\end{array}$ & $\begin{array}{l}\text { Ethyl } \\
\text { acetate } \\
\text { fraction }\end{array}$ \\
\hline Alkaloids & - & - & - & - \\
\hline Saponins & - & - & - & - \\
\hline $\begin{array}{l}\text { Polyphenolic } \\
\text { compounds }\end{array}$ & + & + & + & + \\
\hline Terpenoids & - & - & - & - \\
\hline Tannins & + & + & + & + \\
\hline Flavonoids & + & - & + & + \\
\hline $\begin{array}{l}\text { Steroidal } \\
\text { compounds }\end{array}$ & + & - & - & + \\
\hline Coumarins & - & - & - & - \\
\hline Free anthraquinones & - & - & - & - \\
\hline
\end{tabular}

Key: + indicates presence, - indicates absence

Table 5: Secondary metabolites detected in $80 \%$ methanol crude extract and solvent fractions of the fruits of Rosa abyssinica.

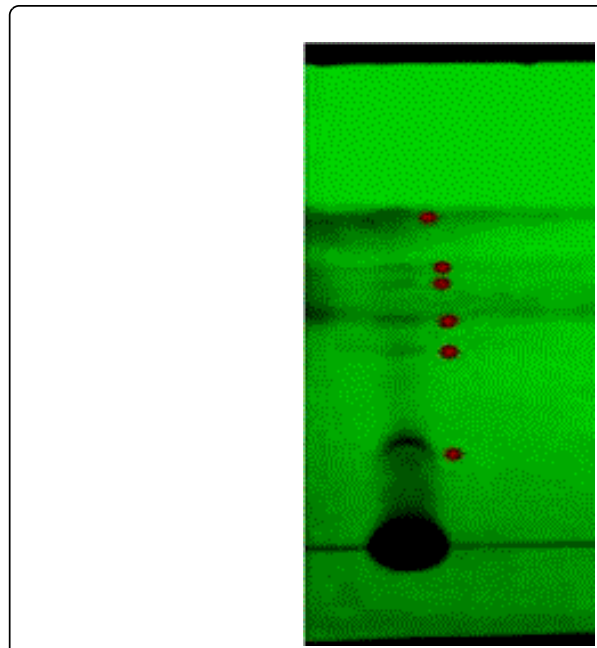

Figure 2: Thin layer chromatography fingerprint of $80 \%$ methanol extract of the fruits of Rosa abyssinica: plate developed by a solvent system containing hexane: ethyl acetate $(1: 1)$ and is observed under UV-light at a short wavelength of $254 \mathrm{~nm}$.

\section{Discussion}

In this study, the antidepressant- like effect of the crude as well as solvent fractions of the fruits of Rosa abyssinica were evaluated using despair based rodent models of depression. The immobility displayed by rodents when subjected to aversive stimuli such as being suspended by the tail or forced to swim in a confined cylinder is thought to reflect a state of despair or lowered mood [37,38]. The duration of immobility has been shown to be reduced by even acute treatment [25] with antidepressant drugs and a significant correlation was found between the clinical efficacy of antidepressant drugs and their potency in both models $[27,39]$.

Male animals were used to screen the potential antidepressant-like activity of the plant. This is based on previous findings that female rats or mice are less susceptible to behavioral suppression compared to their male counter parts due to a higher arousal level even at the basal state [40]. TST was used as the model of choice for assessing the antidepressant- like activity of the solvent fractions for various reasons. First, the "immersion in water" in FST, which is necessary to produce the "behavioral despair", induces hypothermia in animals causing a behavioral change that can affect the result. Second, the ease of identifying immobility in TST as compared to FST makes TST a more suitable model. Third, TST is claimed to be more sensitive to lower doses of drug and provides a clearer dose-effect relationship. Finally, the highest percent inhibition in immobility for the crude extract in this study was seen in the TST as compared to the FST [27].

After administering the test dose of $100 \mathrm{mg} / \mathrm{kg}$, the crude as well as all the solvent fractions failed to show a significant antidepressant-like activity in the TST. This indicates that $100 \mathrm{mg} / \mathrm{kg}$ is a sub-therapeutic dose for this effect. The crude extract as well as the aqueous and methanol fractions exhibited a reduction in the time of immobility at the dose of $200 \mathrm{mg} / \mathrm{kg}$. Additionally, the effect of the aqueous fraction at this dose was relatively better than imipramine. Thus, the aqueous fraction is considered the most effective amongst all fractions, and 200 $\mathrm{mg} / \mathrm{kg}$ could be taken as the maximum effective dose. 
Increasing the dose further produced the highest effect with the crude extract but this trend was not observed in the fractions. In the aqueous fraction increasing dose produced a significant reduction, albeit to a smaller extent compared to $200 \mathrm{mg} / \mathrm{kg}$. By contrast, no apparent change in immobility was observed with $400 \mathrm{mg} / \mathrm{kg}$ of the methanol fraction compared to controls. In the ethyl acetate fraction, one could somehow see a similar trend, even more, there was an increase in immobility at $400 \mathrm{mg} / \mathrm{kg}$ though the change failed to reach statistical significance.

These observations could possibly be explained in a variety of ways as follows: i) The doses of the fractions might not be in the linear portion of the dose-response curve, as there was a prior increase in activity followed by a subsequent drop. Alternatively, the fractions might contain constituents, whose concentration increased with dose and possibly interfere with the activity and this influence might be relieved in the crude extract. ii) Many flavonoids and neuroactive steroids have been reported to be ligands (like benzodiazepines) for the GABAA receptors in the CNS [41]. It is established, that GABA agonists such as diazepam respond to the TST by increasing time of immobility [27]. Thus, lack of effect by the ethyl acetate fraction could be attributed to the presence of steroids and flavonoids in this fraction. Indeed, the absence of both secondary metabolites in the aqueous fraction could probably be the major reason why this fraction was endowed with the highest activity. Another note one should make at this juncture is that the methanol fraction did contain flavonoids but not steroidal compounds. However, this fraction displayed activity at $200 \mathrm{mg} / \mathrm{kg}$, which was lost at $400 \mathrm{mg} / \mathrm{kg}$. This might indicate that steroids could play the major inhibitory role than flavonoids, and a positive role, if any, played by flavonoids is overcome with increasing concentration. iii) It is interesting to note that the antidepressant-like activity of the solvent fractions in the TST decreased with decreasing polarity, possibly indicating to the fact that polar constituents are responsible for the observed effect. iv) The absence of waning of effect with dose in the crude extract reiterates once again the importance of interaction amongst the different constituents that either create synergy or overcome interferences.

FST and TST are similar in their working principle and more often than not the data from these two models is converging [42]. In FST, the crude extract displayed a notable reduction in the duration of immobility in comparison to the negative control animals, which is suggestive of a considerable antidepressant-like activity. The activity of the extract in both models observed in the present study thus strengthens the possibility that Rosa abyssinica indeed is a potential candidate for the treatment of major depressive disorders. The variability in the response of different antidepressants in these models, however, indicates potentially different substrates and neurochemical pathways mediating performance in these tests $[43,44]$. These issues possibly underlie the observed behavioral differences between the two tests in the current study. The highest percent reduction in time of immobility was seen in the TST than FST, possibly due to the fact that any possible confounds induced by stressful hypothermic exposure in the FST are not present in TST.

Even though at this point it's a bit farfetched to decide which phytoconstituents are responsible for the antidepressant-like activity of $R$. abyssinica, it is probably reasonable to attribute the antidepressantlike activity partially to the presence of polyphenolic compounds such as tannins in the extract. Previous studies indicated that tannic acid has been shown to possess a non-selective inhibitory effect on MAO, causing a general elevation of monoaminergic neurotransmission in the brain [45]. Other polyphenolic compounds such as rosmarinic acid and its metabolite have also been reported to have antidepressant activity. Another possible mechanism of action is the attenuation of oxidative stress, by the polyphenols and tannins present in Rosa abyssinica. Exact mechanisms underlying the antidepressant- like activity of the extracts remain to be seen.

It is known that antidepressants do not increase the locomotor activity that is otherwise observed in psychostimulant drugs. Therefore, in order to rule out any possible non-specific motor stimulation the OFT, one of the rodent models of anxiety, designed by Hall in 1934 was used. This test is also used to assess locomotor activity based on total number of square crossings. They instead cause a slight decrease in motor activity and can cause loss of muscle tone. Therefore, the outcome of this test is important to rule out any nonspecific activity of this plant $[25,34]$. In this study, it was demonstrated that the crude extract of $R$. abyssinica didn't significantly alter the spontaneous locomotor activity of mice during the OFT. This is indicates that, at the doses tested, the antidepressant-like activity of $R$. abyssicia is unlikely to be a false positive as a result of psycho stimulant action. But it is noteworthy that, although it was insignificant, there was an increase in the total squares crossed with increasing dose of the extract. This might be a crucial indicator that at higher dose the plant might possess a psychostimulant activity.

\section{Conclusion}

Based on the findings obtained from this study, it is safe to infer that the crude extract as well as the solvent fractions of the fruits of $R$. abyssinica possesses a notable antidepressant-like activity. Further, the outcome of OFT indicates that the plant has no significant effect on locomotor activity suggesting that the antidepressant-like activity observed is not caused by a non-specific motor stimulation. Hence, indepth studies on this plant involving chronic and in vitro studies to indicate the substrates involved in its mechanism of action should be pursued.

\section{Conflict of Interest}

The authors declare that they have no competing interests.

\section{Acknowledgements}

The authors are grateful to Ato Melaku Wondafrash, the National Herbarium, Addis Ababa University for identification of the plant material. NF would like to acknowledge Addis Ababa University for the financial support and for providing laboratory facilities.

\section{References}

1. World Health Organization (2012) Depression: A Global Public Health Concern.

2. World Health Organization (2013) WHO: Global Global Health Estimates (GHE).

3. Al-Harbi KS (2012) Treatment-resistant depression: therapeutic trends, challenges, and future directions. Patient Prefer Adherence 6: 369-388.

4. Vermeiren Y, Van DD, Aerts T, Engelborghs S, Martin JJ, et al. (2015) The monoaminergic footprint of depression and psychosis in dementia with Lewy bodies compared to Alzheimer. Alzheimer's Research and Therapy 7: 7 .

5. Krishnan V, Nestler EJ (2008) The molecular neurobiology of depression. Nature 455: 894-902. 
6. Nestler EJ, Carlezon WA (2006) The mesolimbic dopamine reward circuit in depression. Biol Psychiat 59: 1151-1159.

7. Bouhuys AL, Bos EH, Geerts E, Van OS, Ormel J (2006) The association between levels of cortisol secretion and fear perception in patients with remitted depression predicts recurrence. J Nerv Ment Dis 194: 478-484.

8. Brown ES, Woolston DJ, Frol AB (2008) Amygdala volume in patients receiving chronic corticosteroid therapy. Biol Psychiat 63: 705-709.

9. Cowen PJ (2008) Serotonin and depression: pathophysiological mechanism or marketing myth? Trends Pharmacol Sci 29: 433-436.

10. Saldanha BD, Kumar MN, Ryali SG, Srivastava K, Pawar SC (2009) Serum Serotonin Abnormality in Depression. Med J Armed Forces India 64: $108-112$

11. Nutt DJ (2006) The Role of Dopamine and Norepinephrine in depression and antidepressant Treatment. J Clin Psychiat 6: 3-8.

12. Martinot M, Bragulat V, Artiges E, Dollé F, Hinnen F, et al. (2001) Decreased presynaptic dopamine function in the left caudate of depressed patients with affective flattening and psychomotor retardation. Am J Psychiatry 158: 314-316.

13. Treadway MT, Zald HD (2011) Reconsidering Anhedonia in Depression: Lessons from Translational Neuroscience. Neurosci Biobehav 35: 537-555.

14. Klemens J (2006) Herbs used for psychotropic or Behavior modifying activity. JAAIM 2: 1-9.

15. Rajput MS, Sinha S, Mathur V, Agrawal P (2011) Herbal antidepressants. Int J Pharm Front 1: 159-169.

16. Rojecky LB, Kalodera Z, Samarija I (2004) The antidepressant activity of Hypericum perforatum L. measured by two experimental methods on mice. Acta Pharm 54: 157-162.

17. Getahun A (1976) Some common medicinal and poisonous plants used in Ethiopian folk medicine. Ababa University, Addis Ababa, Ethiopia.

18. Sewuye W, Asres K (2008) In Vivo Anti-inflammatory and Antinociceptive Activities of Extracts of Rosa abyssinica and Salvia nilotica. Ethiopian Pharmaceutical J 26: 75-82.

19. Kheyrodin H (2009) Isolation and identification of new eleven constituents from medicinal plant. Int J Nutr Metab 1: 14-19.

20. Chekole G, Asfaw Z, Kelbessa E (2015) An ethnobotanical study of plants used in traditional medicine and as wild foods in and around Tara Gedam and Amba remnant forests in Libo kemkem wereda, south gonder zone, amhara region, Ethiopia. J Ethnobiology and Ethnomedicine 11: 4.

21. Dolati K, Rakhshandeh H, Shafei M (2011) Evaluation of antidepressant effect of ethanolic extract of Rosa damascene using forced swimming test. Avicenna J Phytomed 2: 46-51.

22. Organization of Economic Co-operation and Development (2008) The OECD guidelines for testing of chemical: Acute oral toxicity- fixed dose procedure. OECD publishing, France.

23. Moallem SA, Hosseinzadeh H, Ghoncheh F (2007) Evaluation of antidepressant effects of aerial parts of Echium vulgare on mice. Iran J of Basic Med Sci 10: 189-196.

24. Murugan U, Suganthi J, Kanmani S (2011) Evaluation of antidepressant like activity of Cucurbita pepo seed extracts in rats. International Current Pharmaceutical Research 3: 108-113.

25. Porsolt RD, Le Pichon M, Jalfre M (1977) Depression: A new animal model sensitive for antidepressant treatments. Nature 266: 729-732.

26. Selvi PT, Kumar MS, Rajesh R, Kathirava T (2012) Antidepressant activity of ethanolic extract of leaves of Centella asiatica. Linn by In vivo methods. Asian J Res Pharm Sci 2: 76-79.
27. Steru L, Chermat R, Thierry B, Simon P (1985) The tail suspension test: A new method for screening antidepressants in mice. Psychopharmacology 85: $367-370$

28. Castagne V, Moser P, Roux S, Porsolt DR (2007) Rodent Models of Depression: Forced Swim and Tail Suspension Behavioral Despair Tests in Rats and Mice. Curr Protoc Pharmacol 38.

29. Velmurugan C, Muthuramu T, Venkatesh S, Vetriselvan S (2013) Antidepressant activity of ethanolic extract of bark of Ougeinia oojeinensis (Roxb.) in mice. IJBPR 4: 382-385.

30. Nisar M, Khan S, Dar A, Rehman W, Khan R, et al. (2011) Antidepressant screening and flavonoids isolation from Eremostachys laciniata (L) Bunge. Afr J Biotechnol 10: 1696-1699.

31. Batool F, Kamal A, Sattar M, Shah A, Ahmed S, et al. (2011) Evaluation of antidepressant-like effects of aqueous extract of sea Buckthorn (Hippophae rhamnoides L. Ssp. Turkestanica) fruits in experimental models of depression. Pak J Bot 43: 1595-1599.

32. Machado DG, Bettio LE, Cunha MP, Santos AR, Pizzolatti MG, et al. (2008) Antidepressant-like effect of rutin isolated from the ethanolic extract from Schinus molle L. in mice: Evidence for the involvement of the serotonergic and noradrenergic systems. Eur J Pharmacol 587: 163-168.

33. Trease E, Evans C (1989) Pharmacognosy. London, Bailliere Tindall.

34. Jager KA, Saaby L (2011) Flavonoids and the CNS. Molecules 16: 1471-1485.

35. Pemminati S, Gopalakrishna HN, Shenoy AK, Sahu SS, Mishra S, et al. (2010) Antidepressant activity of aqueous extract of fruits of Emblica officinalis in mice. IJABPT 1: 449-454.

36. Parra A, Caerols CV, Monleon S, Simon MV (1999) Learned immobility is also involved in the forced swimming test in mice. Psicothema 11: 239-246.

37. Sharma VK, Chauhan NS, Lodhi S, Singhai AK (2009) Antidepressant Activity of Zizyphus xylopyrus. International Journal of Phytomedicine 1: 12-17.

38. Palanza P (2001) Animal models of anxiety and depression: how are females different? Neurosci Behav 25: 219-233.

39. Sajid I, Bijan K, Zamiul R, Mominul I, Ekramul H (2013) CNS Depressant and Antinociceptive Activities of the Aerial Parts of Mimosa pudica. Europ J Appl Sci 5: 127-133.

40. Cryan JF, Kelly PH, Neljit HC, Sansig G, Flor PJ, et al. (2003) Antidepressant and anxiolytic-like effects in mice lacking the group III metabotropic glutamate receptor mGluR7. Eur J Neurosci 17: 2409-2417.

41. Chatterjee M, Jaiswal M, Palit G (2011) Comparative Evaluation of Forced Swim Test and Tail Suspension Test as Models of Negative Symptom of Schizophrenia in Rodents. ISRN Psychiatry 10: 1-5.

42. Cryan JF, Mombereau C (2004) In search of a depressed mouse: utility of models for studying depression-related behavior in genetically modified mice. Mol Psychiatr 9: 326-357.

43. Shekar C, Manohar VR, Rao SN (2012) Antidepressant activity of aqueous extract of fruits of Terminalia chebula in rats. Int J Pharm Pharm Sci 4: 449-451.

44. Emamghoreishi M, Talebianpour MS (2009) Antidepressant effect of Melissa officinalis in the forced swimming test. DARU J Pharm Sci 17: $42-47$.

45. Bourin M, Demouliere B, Dhonnchadha BN, Hascoet M (2007) Animal models of anxiety in mice. Fundam Clin Pharmacol 21: 567-574. 